This item was submitted to Loughborough's Research Repository by the author.

Items in Figshare are protected by copyright, with all rights reserved, unless otherwise indicated.

\title{
Education policy and contemporary politics
}

PLEASE CITE THE PUBLISHED VERSION

PUBLISHER

(C) Palgrave Macmillan

LICENCE

CC BY-NC-ND 4.0

REPOSITORY RECORD

Demaine, Jack. 2019. "Education Policy and Contemporary Politics". figshare. https://hdl.handle.net/2134/618. 
This item was submitted to Loughborough's Institutional Repository by the author and is made available under the following Creative Commons Licence conditions.

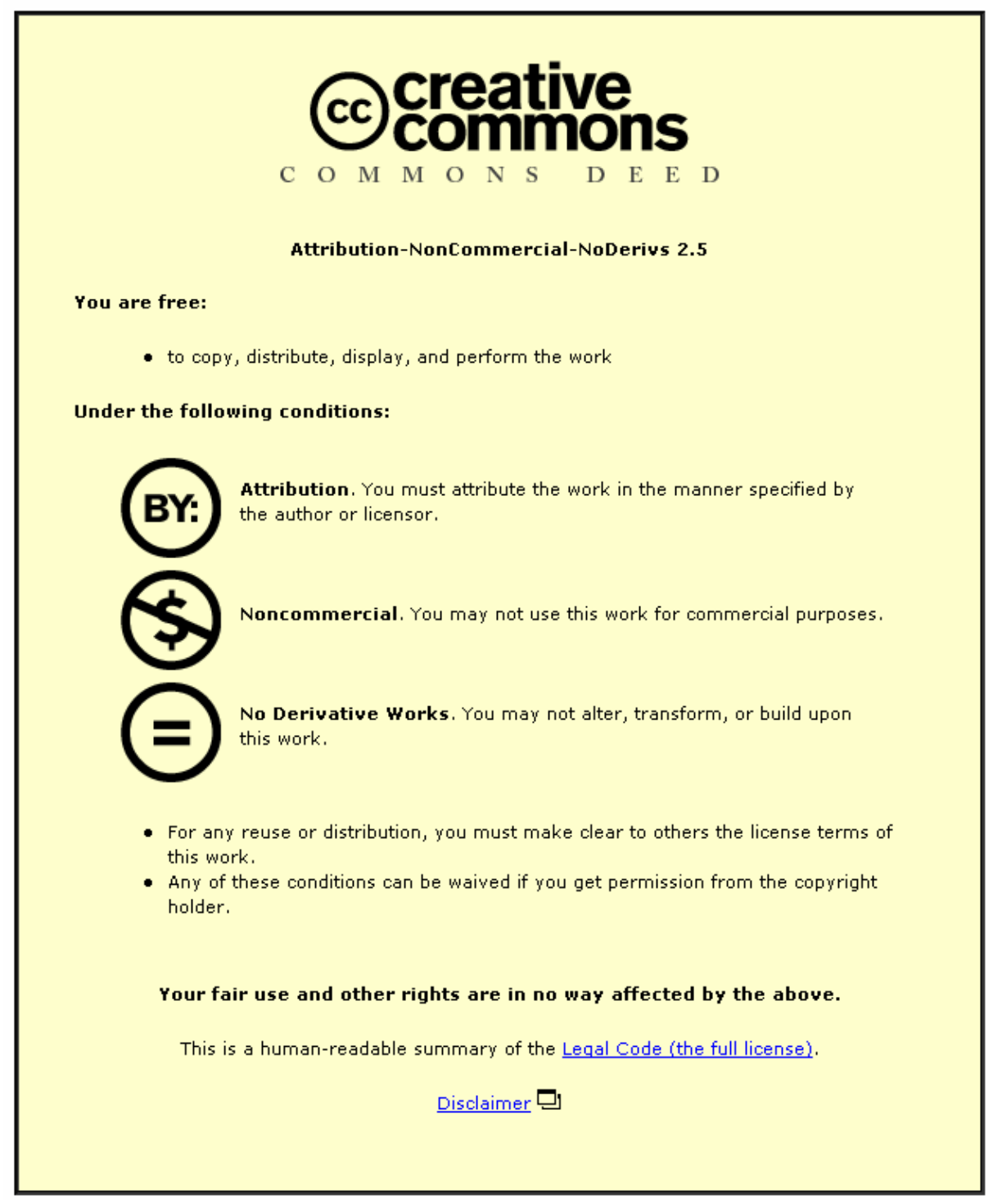

For the full text of this licence, please go to: http://creativecommons.org/licenses/by-nc-nd/2.5/ 
Education Policy and Contemporary Politics (Palgrave Macmillan, 2002, $2^{\text {nd }}$ Edition)

\section{Chapter One}

\section{Jack Demaine}

On May 2nd 1997 Tony Blair, surrounded by enthusiastic supporters, walked triumphantly along Downing Street as Labour Prime Minister with the largest parliamentary majority in modern times; the beneficiary and main architect of a 'landslide' election victory. Eighteen years earlier, during election day in 1979 , the previous Labour Prime Minister James Callaghan, alone with his a close aide Joe Haines, is said to have swept aside a comforting observation as to the Party's prospects. Callaghan perceived what he referred to as a 'sea-change' in politics and indeed the following day Mrs Margaret Thatcher had stood at the front door of 10 Downing Street as Conservative Prime Minister.

In those eighteen years between sea-change and landslide the political terrain, and with it education policy, changed dramatically. At the presentational level Blair (call me Tony) transformed the Labour Party into a nationally electable force for the first time since Harold Wilson won the 1974 general election. At a more fundamental political level, by building on the work already done by Neil Kinnock, Blair played a leading role in transforming Party structures, organization and ideology so that many observers have come to regard 'new' Labour as a party of the centre seeking a 'Third Way' in politics. Which ever way it is to go, education is said to be at the core of the new Labour project. In his political rhetoric in the run-up to the 1997 General Election, Tony Blair used the phrase 'Education, education, education' as clarion call and as a promise of a new future: 'Education will be the passion of my government'. Of course, education was something of a passion for the Conservatives too during their eighteen years in government. They were passionately concerned to reform education because, like Blair, they also regarded it 'as fundamental to Britain's prospects'.

This chapter discusses important aspects of education policy from Jim Callaghan's defeat to Tony Blair's victory; from sea-change to landslide and beyond. In certain important respects, new Labour appears intent on following a similar policy-line on education to that of the Conservatives when they were in office; albeit a line modified and adapted to the politics of the 'real world' in which Labour wants to appear new and different but at the same time pragmatic and 'down to earth'. For example, with respect to the management of schools and the 'policing', of teachers' work, new Labour is hardly distinguishable from the Tories. But there are also aspects of policy where Labour is rather different. For example, embarking on a $£ 1.2$ billion programme of school repairs and building work really is new and different, and Labour's proposed changes to modes of support for students in higher education are something from which even the Tory Right shied away. 
The chapter begins with a brief account of aspects of the politics of education at the end of the Callaghan era, and traces important political developments during the eighteen years of Conservative administration up to the new Labour politics of education and the idea of a 'Third Way'. The chapter does not subscribe to the widely-held view that Callaghan's intervention was the 'cause' of all that was to follow in educational politics, and neither does it suggest that there is particular 'Way' that Labour must look to follow into the new millennium. Rather, what came about during the 1980s and 1990s was the consequence of a complex combination of political conditions and ideology and not 'determined' by some single force, principle or idea. Of forces, ideas and principles there are many, and some of them may be regarded as more significant than others, but their interplay produces outcomes which cannot simply be 'read off' from any one of them.

\section{EDUCATION AND THE SEA-CHANGE IN POLITICS}

Jim Callaghan is said to have been appalled by the events played out at the William Tyndale Junior and Infants School in Islington, North London between 1973 and 1975. The details of those events are set out in the Auld Report (1976), and in the writings of those who disputed the official report; they need not detain us here. The important political issues raised by the William Tyndale affair were those of 'standards', 'accountability' and 'control of education' (see Demaine 1981). Soon after he became Prime Minister, Callaghan made thinly disguised reference to the problems presented at the William Tyndale school in his 1976 Ruskin College Speech, but was careful to distance himself from critics on the political right, saying explicitly that:

My remarks are not a clarion call to Black Paper prejudices. We all know those who claim to defend standards but who in reality are simply seeking to defend old privileges and inequalities (quoted in Ahier, Cosin and Hales 1996).

Nevertheless, some commentators at the time expressed surprise that a Labour Prime Minister should take up the issue of 'standards', which many had seen as a Tory slogan. But more significant is Callaghan's argument that:

It will be an advantage to the teaching profession to have a wider public understanding and support for what they are doing. And there is room for greater understanding among those not directly concerned (ibid.)

In the 1970s, some teacher trade unionists had regarded the notion of 'teacher accountability' as a threat to 'professional autonomy'. With the advantage of hindsight we can see that the issue of accountability was much more than a fashion, and more than a slogan, in a Britain where consumerism was fast gaining a strong foothold. Callaghan's thinking was well ahead of those teacher trade unionists who rejected the recommendations of the Taylor Report (1977); and indeed some academic observers of education at that time (see Demaine 1980). The political issue that brought together the question of standards in education and the issue of accountability was, of course, the 
issue of 'control'. The William Tyndale affair appeared to demonstrate, night after night via the television screens in people's homes, that central government was not in control of education. Of course, central government had 'residual' powers that could be invoked, but the Education Act (1944) had placed much of the education system in the hands of the local education authorities (LEAs). Conservative governments' efforts during the 1980 s were to be focused on shifting power away from the LEAs.

By present-day standards William Tyndale was a shocking affair. That it seems so now, demonstrates how far education reform has moved on since Labour was last in office. The Auld Report had found a school out of political control and the Taylor Report sought to devise mechanisms through which schools might be made accountable to their local community. Callaghan's Ruskin College Speech, his government's acceptance of the findings of the Auld Report, and subsequently the Taylor Report, set the context for aspects of reform that were to be enacted by the Conservatives when they came into office. As Batteson (1997) rightly argues, it is quite wrong to regard Callaghan's 1976 speech as somehow the 'cause' of those developments. Nevertheless, new Labour can now be seen to be continuing to develop policy-themes which were set out by old Labour and carried through by the Conservatives.

The Taylor Report had recommended a formal structure for the election of parents, teachers and community representatives to the governing bodies of schools. The new bodies would take on greater responsibility for overseeing the management of schools, although the 'day-to-day' management would remain in the hands of head teachers and their senior assistants. During the 1980s the Conservatives implemented many of Taylor's recommendations; although not in precisely the way delineated in the report. But of course, the Conservatives in office wanted much more. A major difference between Taylor's recommendations and the Tory plans for market-oriented school 'selfmanagement' was the issue of school finance. Taylor had not recommended devolution of financial control to the individual school, although it did recommend that the local authorities 'involve' governors more in the drawingup of expenditure plans along the lines of the 1945 'model articles' for school management (see Taylor Report, chapter 7).

In contrast with Taylor's rather modest recommendations, radical proposals for financial self-management came from the so-called 'new right'. In modifying the radical right's policy proposals, the Conservatives found a way in which to appear to 'empower' the individual school whilst shifting more control to central government. The Tories used the radical right's rhetoric on 'liberalisation' to wrench power from the hands of the LEAs. New Labour is now the beneficiary of 'central control of education'; a possibility that Stuart Sexton (1987) had always warned against. He and others on the neo-liberal right had wanted to see the development of a system of 'self-managed' schools 'free from State controls' (see Demaine 1990). What was actually to developed during the 1980s and 1990s was the consequence of a complex combination of political conditions and ideology. 


\section{EDUCATION AND LABOUR IN OPPOSITION}

In the period following Labour's defeat in the 1979 General Election the Party turned left and, in Denis Healey's view, thus condemned itself to further defeats in the next two general elections (Healey 1989). Callaghan resigned as Party Leader in 1980 and was replaced by Michael Foot who led the Party to a disastrous defeat in the 1983 General Election. Gerald Kaufman described Labour's election manifesto as 'the longest suicide note in history'; rightly according to Healey. Neil Kinnock became Party Leader just after the 1983 election and, although he took a leading role in making very important changes to the Party, he went on to lead Labour to further defeats in 1987 and 1992 before handing over to John Smith.

During their long years in Opposition, Labour had many critics both inside and outside the Party. Although education had been regarded as one of its strengths, critics argued that even here Labour had lost its touch. In a paper titled, The Labour Party's Education Policy on Primary and Secondary Education 1979-89, Bill Inglis (1991) maps out how he thinks Labour 'lost the initiative' to the Conservatives. He argues that for almost a decade between 1979 and 1987, and particularly during Giles Radice's tenure as Opposition spokesperson, the Party's approach to education policy was 'complacent' and there was a failure to prepare for the 'Conservative challenge' in the late 1980s. Radice's Fabian pamphlet, Equality and Quality: A Socialist Plan for Education (1986) and the discussion of education policy in his book Labour's Path to Power, is said to be 'disappointing'. Later, according to Inglis, complacency was 'replaced by a mixture of acceptance and defensiveness' (Inglis 1991, p. 5). Inglis is most vitriolic in his attack on Neil Kinnock, who was Shadow Education Secretary in the early 1980s. Curiously, Kinnock's own book Making Our Way (1986) is ignored and instead Inglis refers to a much earlier piece on education policy published in Gerald Kaufman's Renewal, Labour's Britain in the 1980s. Kinnock's chapter in that book is said to involve, 'a facile attack on the elitist academic tradition of British schools' and is 'suffused with a proselytizing optimism' (Inglis 1991, p. 13).

A different reading of Making Our Way would see Kinnock taking on the Conservatives in a way that could hardly be called complacent or defensive, as Inglis asserts. Indeed, readers will find a Labour Party leader coming to terms with the need for change and recognizing both the significance and the danger of consumeristic thinking. Whilst attacking the Conservatives and insisting that, as far as Labour is concerned, education should not go to market, Kinnock argued perceptively that:

The objectives of choice, standards, and relevance must be central themes of education. They have been debased by the present government in order to mobilise prejudice, feed propaganda and provide excuses for narrowing and reducing provision - and therefore choice, standards and relevance - for the great majority of school children. The expansion of choice, the raising of performance standards, the increase of relevance, together with other objectives of education like social and 
cultural enlightenment, good behaviour, responsibility, self confidence, the encouragement of the appetite for knowledge, the fulfillment of potential, the development of the individual regardless of sex, or race, or economic circumstances, are desirable. But they are only significant if they are supported and reinforced by adequate resources and implemented in a partnership with the professionals that can foster success. Choice is mocked as the pressures of shortages push another generation into old, narrow avenues, and when confrontation rather than co-operation informs relationships among government, teachers and education administrators. (ibid., p. 139, emphasis in the original).

Kinnock does not simply reject the consumerism that the Conservatives were keen to extend to education. He accepts that choice is important but turns the argument against his opponents. Conservative policy gives choices to the few as shortage of resources reduces choice and educational opportunity for the majority. Solutions lie in better co-operative relationships together with adequate resources, and Kinnock makes several points that are not dissimilar to those made by A. H. Halsey in a paper titled Democracy for Education? (Halsey 1981).

Halsey is significant here because he had long been regarded as one of the most important academic influences on Labour's education reform programme during the 1960s. His commitment to comprehensivisation was beyond question but in 1981 he began to argue that modern education systems were becoming 'formidably bureaucratic'. He expressed concern about the 'negative effects of administrative and professional organization' and argued for more 'parent power plus direct grants for all'. Halsey suggested that self-managed schools financed by central and local taxation could make,

every school a direct grant school. School government could be simultaneously reformed along the lines recommended in the Taylor Report, with more power to parents (Halsey 1981, p. 347).

Halsey's proposals presented something of a challenge to those on the left who were locked into thinking that provision of education via the local education authorities could be the only acceptable means through which to organize schooling. But, like Kinnock, Halsey differs from the Conservatives on the question of the market, and he suggests that a direct grant system of schools could be adapted to provide extra funding for schools with children from less well-off families.

A. H. Halsey and Neil Kinnock's writing shows that Labour did not ignore the Conservative challenge, nor did they display a lack of interest, complacency, defensiveness or lack of initiative on education policy as Inglis asserts (see Demaine 1992). Their real problem was that they were unable to win general elections. Under Kinnock's leadership the Labour Party took its electoral predicament very seriously indeed, and in the wake of defeat in the 1987 General Election began a thorough review of its policy. In the Final Report of Labour's Policy Review for the 1990s, Meet the Challenge Make the Change 
(1989), and in the pamphlet Parents in Partnership (1988), Labour committed itself more firmly than ever to the idea of partnership between parents, schools and LEAs and to the recommendations of the Taylor Report. Indeed, Parents in Partnership goes so far as to suggest that parents are the 'cornerstone of a school's success and a pupil's progress' and that 'Labour wants to build a firm bridge between home and school'. The Labour Party has a well established record of seeking to develop the themes of involvement and partnership, in contrast to the right's relatively recent rhetoric on 'parent power', and 'parental choice'. We now turn to the right.

\section{THE CONSERVATIVES AND THE NEW RIGHT}

Consumerism, and in particular the notions of 'parental choice' and 'the market' became important themes in Conservative education thinking during the 1980s. The government appeared to be attracted to a line of argument set out by the 'new right' although they did not follow it slavishly; as we shall see in a moment. The term new right (see Bosanquet 1983) refers not to any specific group but to a movement represented by a collection of lobby groups concerned, amongst other things, to bring about the 'liberation' of public services from 'excessive state control' through their 'privatisation'. The political philosophy of the new right is that of 'liberalism', defined in F. A. Hayek's (1960) sense of limiting the powers of government in the interests of the liberty of the individual and a 'free society' (see Hindess 1987). As far as education is concerned, the new right seeks the transformation of school systems, so that individual schools would become individual self-managing 'private' institutions. As one leading proponent of new right thinking explains, 'the plan is to create, as near as practicable, a "free market" in education. To use a popular term, it is in some sense to "privatise" the State education system' (Sexton 1987, p. 10).

The new right argues that education must be regarded as a commodity; teachers regarded as producers and parents (rather than children) as the consumers. Education provides an inadequate service when it suffers from the effects of 'producer capture'. According to the right wing Adam Smith Institute's Omega Report: Education Policy (1984), producer capture is evident when education serves the interests of teachers and administrators rather than the interests of consumers. The hallmarks of producer capture of education are said to include 'employment laxity, giantism and resistance to change' (p. 3). The new right sees producer capture as a central characteristic of 'Welfare State Socialism', and the post-war British comprehensive school system as a clear example. The remedy is said to be an 'education voucher' and a system of self-managed schools in which parental interests are strongly represented, and governing bodies are free to 'free to hire and fire' teachers. The new right argues that the provision of such arrangements would 'liberate' schools, and place them into market relationships leading to an improved education 'service'. Some on the right see the liberation of education as a possible task still to be achieved. 
The idea of education vouchers is not new and there are differences between the various proposals that have been put forward. Schematically, the suggestion is that every parent or legal guardian of a child of school age would be issued annually with a voucher on its behalf. The value of the voucher, sometimes referred to as a 'credit' or 'entitlement' would be that of the average per caput cost of schooling within a specific locality, taking into consideration differences in costs for children of different ages. Schemes recommended by the new right suggest that parents should be allowed to 'top up' the value of the voucher with cash and spend both in a 'free market' for education (Sexton 1987). According to the new right one of the obstacles to the development of a free market is the way in which teachers' pay and working conditions are determined. In a future that is imagined by the new right, privatised self-managed schools would need to be able to appoint teachers on fixed-term contracts if they so wish, and hire and fire very much more easily than has been the case so far. In a free market, teachers' salaries would 'no longer be determined on a national basis, but by each school. Schools might wish to institute different grades of salary for different qualities of teacher' (Adam Smith Institute 1984, p. 7). But whilst teachers' pay and conditions are thought to present a serious obstacle, the main obstacle is the 'state provision of education', as such, because it has established a context which has the effect of frustrating consumer choice.

The right concedes that in Britain the development of a system of private self-managed schools where the producers are exposed to the rigours of the market, and the paying customers exercise their consumer rights, cannot be achieved overnight and could not be achieved without the political force of central government. Some observers regard this as something of a paradox; the 'liberation' of schools from 'political control' and the creation of independent self-managed schools could only be brought about by the political power of central government. For the libertarian right this presents an obvious danger. As Stuart Sexton argues, centralisation of control of education is 'unsatisfactory and objectionable, especially in England where the whole concept is alien to our ideas of personal liberty and freedom' (Sexton 1987, p. 7). Nevertheless, centralisation might be thought tolerable in the short term, if it held out the prospect of eventual liberty for the consumers in a market for education. But once central government had taken control it might not let go. As we shall see, Stuart Sexton's worst fear was that Conservative central government might seize power in the name of liberty, only to lose it to an incoming 'socialist' government.

Now, although it is important not to overestimate the extent and capacity of centralisation to bring about effective reform, it did provide the Conservatives with mechanisms through which to curtail the activities of LEAs and to steal political control from Labour councils during the 1980s and 1990s. Understandably, centralisation was the focus of much criticism from both the left and the right. As far as the education voucher is concerned, the Conservatives began to distance themselves from the idea in the early 1980s following damaging publicity surrounding a feasibility study carried out by the then Conservative controlled Kent County Council. Sir Keith Joseph, Secretary of State for Education and Science, told the 1983 Conservative 
Party Conference that, 'the voucher, at last in the foreseeable future, is dead.' (quoted in Seldon 1986).

Following Sir Keith Joseph's speech, the new right in Britain had to concede that the introduction of vouchers and privatisation would not be achieved quickly because 'politically and financially it would not be possible or desirable to make a sudden change' (Sexton 1987, p. 30). Stuart Sexton set about devising a plan for what I have referred to elsewhere as 'privatisation by stealth' (Demaine 1989). In his influential pamphlet, Our Schools: A Radical Policy (1987), Sexton explains that there should be a 'phased introduction of educational credits, with every step a gentle step' ( p. 46). He presents detailed plans for a process of gradual reform, delineating three distinct stages. What he refers to as 'gradualism' is required because by making slow progress towards privatisation there will be less likelihood of 'offending the educationists and the bureaucrats' who are said to have 'enormous vested interest' in the status quo (p. 4). Since 'the public' needs to be introduced gently to the idea of paying for education in a 'free market', a step towards this long-term objective is the implementation of a scheme of direct grants from central government to the newly opted out self-managed schools. Once the cost of education is more fully understood and accepted by the public (something that has not really happened in Britain) the next stage would be to allow those direct grants to be transformed into education credit vouchers that parents would receive directly from government. Eventually there would be legislation to allow credit vouchers to be topped up with cash and used at any school competing for custom in the market-place. The distinction between public and private, between 'state' and independent school, would eventually be dissolved, says Sexton.

During the 1987 election campaign Mrs Thatcher, clearly influenced by Sexton's pamphlet, thus played down the idea of education vouchers. She told an interviewer who asked about them that 'something much more simple is required', and suggested that instead 'a headmaster (sic) would get so much money per pupil and he would be free to spend a proportion of that how he liked' (see English 1987). Thatcher was alluding to the idea of the direct grant maintained schools and to local financial management of schools which were to be legislated for in the Education Reform Act (1988). Later, Kenneth Clarke, who was Secretary of State for Education and Science in the run-up to the 1992 election, also played down the idea of vouchers and instead vigorously promoted the direct grant maintained schools.

So as the Conservatives pressed on with their programme of reform, the voucher was not to be found at the cutting edge of policy. However, Hywel Thomas (1990) observed, that what emerged was a 'voucher economy' without the need actually to print the vouchers; the children themselves became a kind of 'walking voucher'. For political reasons, vouchers and privatisation had been kept off the official agenda whilst 'market forces' were gradually brought to bear on education. This cautious approach, a sort of 'ultra-gradualism', frustrated sections of the right and Arthur Seldon, for example, argued that the Conservatives had 'implemented half-measures, in education, opting out by schools rather than parents, that will delay the best 
solution by a decade' (Seldon 1988). His 'best solution', to force schools to privatise, was ignored, and soon after the 1992 election new legislation was introduced which only went as far as making opting out easier. Whilst in power the Conservatives remained committed to the idea of self-managing schools in the context of a system of central government funding and supervision. From the new right view-point there was far more centralisation than liberalisation and (most cruelly of all as they see it) a Labour government was able to inherited newly acquired 'central power' over education.

\section{THE 'THIRD WAY’ IN EDUCATION?}

John Smith died in May 1994 and Tony Blair was elected as Leader of the Labour Party. His intention to focus on education, and particularly on 'standards in schools' (Blair 1994), was evident from the very start of his tenure as Leader. By the time he became Prime Minister, in May 1997, schools were more deeply involved in their own management than had ever been the case when Labour was last in power. However, the selfmanagement exercised by the governors, managers and heads of educational institutions has to be seen in the context of very much tighter Treasury controls over education expenditure and the activity of various agencies and quangos deployed by the Department for Education and Employment (DfEE) to oversee the curriculum, and inspect standards in schools, colleges and universities. New Labour had no plans to turn the clock back to the 1970s.

Now, neither the principle of centralised control nor the principle of cooperative self-management is anathema to traditional Labour thinking and there is no necessary conflict between them. As we already seen, Halsey argued long ago for school self-management within the context of a national system for education. Of course, the 'new way' suggested by Halsey in 1981 has certainly not been achieved because of his advocacy of it. Rather, the Conservatives found their own way as they tried to combine the ideas of neoliberalism with those of the traditional 'presevationist' Tories (see Knight 1990). The Education Reform Act (1988) combines the idea of a National Curriculum and national policy with plans for the devolution of the management of educational institutions and market reform of education, and although there is a certain amount of 'tension' between the different principles involved in the Act, this does not in itself make the Act unworkable. Of course, there are other issues raised by the question of the process of implementation of policy which are discussed by Ball and his associates (see for example, Ball 1990; Bowe, Ball and Gold 1992). But a broader question arises as to whether the 'new way' Halsey recommended in 1981, and that followed by the Conservatives between 1987 and 1997 amounts to a 'Third Way' that new Labour will also follow now that it is in power.

Julian Le Grand (1998) argues that the government 'is too swamped by the day-to-day preoccupations of office to engage in the necessary reflection' that would afford it the capacity to confirm or deny that it had found or was following a new 'Third Way'. He suggests that we can only try to draw conclusions from what Labour has actually done in respect of the welfare 
state and local government. 'And here there does indeed seem to be something of a pattern. Moreover, it is one that is not neo-liberal or social democratic, but something different: a true Third Way'. Le Grand argues that new Labour is not the new right in new clothes, nor is it 'socialism' of course, but 'in many of the government's actions there is clearly a belief in the value of community, especially local community' (p. 26). Labour's consultation paper, Modernising Local Government (1998) is concerned with making local government more accountable; hence the need for more parental representation on LEAs as well as on school governing bodies. For Le Grand, the themes of community, opportunity, responsibility and accountability spell 'Cora: a worthy rival to Mrs Thatcher's Tina - There Is No Alternative'. Tony Blair's Third Way is said to provide a 'real alternative' and, although it would not necessarily be the Le Grand's way, he suggests that it represents a set of values that Labour hopes will go down well with readers of 'the Sun, Mirror and Daily Mail, for that is where the next election will be won' (Le Grand 1998).

According to several observers, Labour is still searching for a Third Way (see Lloyd and Bilefsky 1998; Walker 1998). In some areas of social welfare 'new ways' are only just being unveiled to public gaze but as far as education policy is concerned it might be argued that giant strides along a Third Way appear to have been taken already. However, there is no monopoly on policy analysis and Steven Teles argues that what really lies at the core of new Labour's philosophy lies an American import - new paternalism. He suggests that like all paternalistic approaches it 'uses the state to enforce, rather than merely encouraging individuals to conform to values that are generally noncontroversial' (Teles 1998). This is clearly so for much of Labour's education policy; few 'sensible middle class parents' would disagree with much of Excellence in Schools and nor would readers of the Sun, Mirror and Daily Mail.

Not withstanding these new perspectives, Labour's education policies involve an overriding pragmatism which takes advantage of the prevailing political conditions. If Blair's way is neither old left nor new right, and it proves acceptable to such a wide range of voters, this is at least in part due to the effects of the policies of previous governments. Teachers and teacher unions have been stripped of much of their power and influence so that what Blair's government can do now is very different from what was possible for Callaghan's government. Whilst the policies for the policing of teachers and present modes of management of schools do appear to fit comfortably into the idea of a Third Way, in an important sense there are no 'ways' but only possibilities contingent on a range of circumstances themselves partly the products of earlier conditions. Labour is able to make progress on education not because it has invented some new third way but because its pragmatism is built on a recognition of the way that educationists have been treated over the last two decades and on the way education system already been reformed. 


\section{The management of schools in the new era}

Whilst the new right was politically active and forceful in arguing for education reform others, who make no claim to right wing credentials, were writing enthusiastically about school self-management. For example, Caldwell and Spinks in their book The Self-Managing School (1988) and Hill, Oakley Smith and Spinks in Local Management of Schools (1990), amongst others, argue that the proper management of schools is best achieved through partnership and the cooperative participation of parents, teachers, local politicians and community representatives, within the context of national policy. In their book The Self-Managing School, Caldwell and Spinks (1988) define a selfmanaging school as,

one for which there has been significant and consistent decentralisation to the school level of authority to make decisions related to the allocation of resources. This decentralisation is administrative rather than political, with decisions at the school level being made within a framework of local, state or national policies and guidelines. The school remains accountable to a central authority for the manner in which resources are allocated (p. 5).

Caldwell and Spinks see no necessary contradiction between school selfmanagement and accountability to a central authority. Enthusiasm for such an arrangement can be found in the early British literature which saw local management of school (LMS) as presenting 'new opportunities' and a 'challenging environment' in which to deliver the education service (see Coopers \& Lybrand 1988). By the mid 1990s these arguments had been largely accepted and, although it is recognized that LMS imposes new demands on headteachers and school governors, budget devolution has been welcomed by many institutional leaders (Cauldwell and Reid 1996). There can be no doubt that carefully planned and well resourced individual school selfmanagement can appear very attractive, particularly to the heads and governors of schools that are the winners in the education market. A national policy and framework for self-managed community-oriented schools is regarded as having the potential to make available the energy and enthusiasm which both the right and the left argue is locked out of the schools by the effects of bureaucracy and by unacceptable 'professional' practice. Such a framework affords an opportunity to develop the principles of 'social justice' and 'stakeholding' through renewed cooperative endeavour on the part both of local and national agencies. Of course, it remains to be seen to what extent cooperative endeavour and the pursuit of social justice will be allowed to take precedence over exigencies of the market.

If the new Labour government is to address the question of social justice in education it must take seriously the evidence of the effects of poverty and inequality on educational opportunity (see for example, Smith, Noble and Smith 1995). Limited moves in the direction towards social justice for children at their schools will not provide them with 'really equal' educational opportunity because the latter involves much more than schooling. Thirty 
years ago, in a seminal paper commissioned by the Joint Education Committee of the New Jersey Legislature, James S. Coleman (1969) demonstrated convincingly that the notion of equality of educational opportunity is 'a mistaken and misleading concept'. Coleman is no right wing elitist. Indeed, he wants to strengthen, and make more meaningful, the 'spirit' or ethos which the phrase represents. Coleman suggested that this can best be attained by using an alternative phrase, 'reduction in inequality' - does not add the words 'of educational opportunity' to the end of this phrase because he regards inequality as involving a wide range of social conditions and institutions, and not just schools. In Britain too, it is recognized that educational opportunity is conditioned by a range of factors; many of which are outside the influence of teachers and schools. Although schools which serve children from the poorest families cannot be expected to 'compensate' entirely for the 'deprivations' the endure, a government which calls itself Labour is expected to make serious efforts in the field of education, and educational expenditure policy, and to combined these with other appropriate welfare policy.

Labour's White Paper, Excellence in Schools (Cmnd. 3681) signaled what might be regarded as a small step in the direction of social justice by proposing the targeting of schools 'in need' through a policy for Education Action Zones (see Bilefsky 1998; Wilby 1998). But, of course, much will depend of the precise detail of the conditions involved in establishing such zones (EAZs), and there is a rather different prospect at hand for the so called 'failing schools'. Labour has indicated the possibility that the running of such schools or groups of schools might be handed over to private companies as has happened in some states in America (Wilby 1998). In Britain, the National Union of Teachers has pledged 'to block any scheme under the government's EAZ initiative to allow private companies to run schools' (Bilefsky 1998). New initiatives which recognize and utilise opportunities to target appropriate funding and expertise to schools and children in need, rather than the profits of private companies, would be the way forward for a government that attached a high priority to the notion of social justice.

Changes in the structure of financing of schools need to be accompanied by serious consideration of the quality of school life. The now well established National Curriculum necessarily provides the starting point for future reform. Although there is broad consensus between the main political parties over the notion of a National Curriculum there remains scope for argument over the detailed content (see for example, Levine 1996) and particularly over the forms of assessment involved (see Murphy and Wilmut in chapter 7 of this book). There are technical and pedagogic matters on which there needs to be much further consultation with teachers, their representatives and other knowledgeable parties. Labour needs to create new structures for its review of the school curriculum beyond 2000 and these are likely to involve the new General Teaching Council. As well as the technical and pedagogic issues raised by assessment, there is the issue of the publication of test and examination results and the drawing up of league tables which have been regarded as one of the main tools in the attempt to establish and operate a market in education. 
In Opposition David Blunkett had argued that the Labour Party was 'not shy of the benefits of information about schools' but added that, 'it is important that league tables are used to help to lever up standards in schools that are underperforming - and not damage them' (Blunkett 1994). The potential for damage in league tables lies in what he referred to as their employment 'as the public hand of a market system in education'. Now in government, Labour has an opportunity to address some of the differences between schools which have been accentuated by the development of a quasi market. Labour has an opportunity to address aspects of social inequality in pursuit of social justice and to concern itself with structures as well as schools; a point to which we will return shortly. To say as much is not to suggest that principles of social justice will always take precedence either in the minds of those parents who have the opportunity to assert their preferences in the education market, or indeed in the minds of leading politicians. Labour is not likely to develop its education policy by making a simple choice between social justice and the market but by trying to combine them in new ways.

In fact, Tony Blair has demonstrated that he is personally committed to the effective expression of parental preference but also to aspects of the argument on social justice. The Blair family choice of an opted out school for their children's secondary schooling understandably offended those Labour Party activists who had campaigned long and hard against opting out and achieved considerable success in mustering anti-opting out votes at individual schools. But of course one of the political effects of Blair's decision was to send a signal to others, whose votes he and his Party needed to win the general election, that old Labour thinking had been supplanted by new Labour. Blair reinforced the message when he supported a close Cabinet colleague on a similar personal decision. But, one of the problems for ordinary parents who are successful in placing their children in the 'right school' is that in so doing they secure no guarantee over the qualities and capacities of the individual persons who will actually teach their offspring. The question of the qualities and capacities of the teaching work-force is addressed by recent discussion of the recruitment, appraisal and 'training' of teachers (Hartley 1998) and more broadly in the discussion over the question of the introduction of a General Teaching Council.

\section{A General Teaching Council and the policing teachers}

The idea of a General Teaching Council involves setting up a new body with the aim of enhancing the 'professional' status of teaching. The idea has support across a wide spectrum of opinion beyond the political mainstream. The radical right supports it although, as we shall see, what they have in mind is rather different from what is proposed by the teaching unions and professional associations. During the 1980s the idea of a GTC was discussed under the umbrella the Universities Council for the Education of Teachers (UCET) but its working party was, at that time, unable to find sufficient consensus on the issue; mainly due to the opposition of the National Association of Schoolmasters and Union of Women Teachers (NASUWT) 
which refused to accept, 'either in principle or in detail', the working party proposals set out in a consultative document on the roles and functions of a GTC (see Sayer 1989). Those proposals envisage a GTC that would be concerned with teachers' qualifications, registration, supply, initial training, induction, in-service education, professional discipline, research and with 'external relations' but that 'salaries, pensions and conditions of service should remain firmly matters for employers and unions'.

Now this is a rather different notion of a GTC from that envisaged by the likes of Dame Mary Warnock, a Conservative Party adviser on education policy, who argues for a GTC on the grounds that, 'teachers would gradually cease to be predominantly unionised' and that instead, they would become 'professionals comparable to doctors or lawyers'. Indeed, the title of the proposed body mimics that of the GMC - the General Medical Council although attempts to equate teachers' work with that of doctors, or lawyers, have never been particularly helpful (see Demaine 1995). Stuart Sexton elaborates the new right view on a GTC as part of a more general political argument on the privatisation of the education system. As we have already seen, the new right regards the break-up of teachers' capacity for trade union activity as an important prerequisite of privatisation. The new right elaborates a notion of 'professionalism' which refers to teachers' status as 'producers of services in a market'. Sexton argues that a GTC should be established by Royal Charter and that teachers could win their membership and retain their 'professional status' only by keeping to a 'no strike' contract. Teachers taking 'unprofessional action' and breaking such a contract would 'by their own selfselection, be weeded out'. The true professionals on the other hand would be allowed to have 'letters after their name, perhaps Fellow of the College of Teachers' (Sexton 1987).

The perceived threat to traditional trade union rights formed a significant part of the NASUWT objection to the idea of a GTC but they eventually dropped their opposition to discussions and UCET was later able to announce that all of the 'major professional associations were in broad agreement on the roles and functions for a GTC'. The teacher unions are willing to engage in detailed discussion about a GTC although not, of course, on the terms presented by the right. Not surprisingly, the teacher unions want a GTC 'alongside' rather than as an alternative to teacher trade unionism.

In their 1997 election manifestos all the main parliamentary parties gave qualified support for the consideration of the idea of a GTC. Much earlier, in its policy review for the 1990s the Labour Party had said that it would 'consider carefully the establishment of a GTC' - indicating that it would seek to secure and enhance the status of the teaching profession. In July 1997, the new Labour government published Teaching: Higher Status, Higher Standards: General Teaching Council: A Consultation Document (DfEE 1997) in which the promise was made that,

by 2000 there will be a General Teaching Council which will: act as a single voice for the teaching profession; be independent of government; assist in the raising of standards in the classroom; advise on the quality 
of those entering the profession; give guidance on the framework for assessing a new entrant's induction year; have a role in barring individuals from the profession; advise on the standards of medical fitness to teach; establish agreed standards of conduct; and promote teaching as a career (DfEE 1997, p. 4).

The consultation document was generally well received, and Excellence in Schools confirmed the government's intention to legislate to establish a GTC. The White Paper also made what now appears to be an obligatory reference to the General Medical Council and the Law Society, followed by a statement that 'Teachers' professional standing should be underlined by the establishment of a General Teaching Council'. However, in early 1998 those institutions involved in recruiting people to courses leading to qualified teacher status (QTS) where reporting 'shortages' of candidates and there was much talk of 'a crisis in recruitment'. There was no such crisis in recruitment to the supposedly comparable professions of law and medicine. Serious questions remain over teachers' rates of pay and working conditions - especially the perception of an occupation over-burdened by bureaucracy and continuously under supervision - and it is clear that government needs to do much more than assert the professional status teaching. A GTC is unlikely to be sufficient in itself to raise the status of teaching and, of course, there are those who will caution Labour to be wary of completing another element of the right wing agenda for the policing of teachers. The effect on teacher recruitment and teaching quality might not be of the kind the government wishes to achieve; especially if a GTC is allowed to develop even more aggressive mechanisms for the policing of teachers which might be regarded as a further denial of professionalism. To say as much is not to argue for 'teacher autonomy'. But there is a real danger that the assertion of the professional status of the occupation of teaching will fail to match potential recruits' perceptions, and that the references to law and medicine will merely have the effect of highlighting the status difference of teaching. What really matters to teachers, and potential recruits, is the support they might expect to receive, their working conditions, their rights as well as their responsibilities as workers and their prospects for decent rates of pay during their careers, and not pretentious and spurious comparisons with other occupations or having a few extra letters after their names.

\section{Labour's promises for education in 2002}

New Labour made a list of promises to the electorate during the 1997 election campaign, as part of what Tony Blair referred to as 'my contract with the British people'. In fact, there were differences in the promises made to the electorates in different parts of the Kingdom but in England the 'five early pledges' included policy on 'fast track' punishment for persistent young offenders; cuts in NHS waiting lists; getting under 25 year olds off benefit and into work; setting 'tough rules' on government spending and borrowing to try to ensure low inflation and strengthen the economy; and for schools, there was a specific promise of cuts in class size to 30 or under for 5,6 and 7 year olds by the year 2002. Excellence in Schools set out a very much longer and 
more detailed list of promises, insisting that by the year 2002 'there will be greater awareness across society of the importance of education and increased expectations of what can be achieved' and that 'standards of performance will be higher'. Labour's 'overall approach to policy will be underpinned by six principles: education will be at the heart of government; policies will be designed to benefit the many, not just the few; the focus will be on standards, not structures; intervention will be in inverse proportion to success; there will be zero tolerance of underperformance; and government will work in partnership with all those committed to raising standards' (Cmnd. 3681, p. 5, emphasis added).

Labour's promises involve a way of thinking about education that Tony Blair sums up by the phrase 'schools not structure' in his book New Britain: My Vision of a Young Country (Blair 1996). The phrase is reproduced in Labour's 1997 election manifesto and reappears in a slightly modified form in Excellence in Schools. The phrase tells us much more about new Labour ideology than the mantra 'education, education, education'. Blair's argument is that the focus should be on schools rather than on the social context in which they are to be found, or on the question of the social range of difference between schools that has been encouraged to develop in recent years. Unlike Mrs Thatcher, Tony Blair knows all too well that there is such a thing as 'society', social difference and a wide social range of schooling opportunities. Why else would he have risked his personal political credibility within the Labour Party by exercising 'parental choice'? But rather than the mantra 'education, education, education', his slogan should read 'schools, schools, schools' and indeed Labour appears even keener on the question of standards in those schools than was Thatcher or Major, and very much more able to address the matter than was Callaghan's government. The focus on school standards and on the policing of teachers' work lies at the heart of Labour strategy for better education.

Whilst Labour hopes to be able to breath new life and a new 'spirit' into schools, Blair signaled his Party's intentions on 'standards' with an announcement well before the 1997 General Election Mr Chris Woodhead, the Conservative appointed Chief Inspector of Schools, would be retained in his post as the head of the Office for Standards in Education (Ofsted). The misgivings that Mr Blunkett had about league tables whilst in Opposition do not seem quite so urgent in Government; although, as promised, he does appear keen to make progress on the assessment of the 'value added' to the quality of a child's academic ability by attending school. And of course, physical structures can no longer be neglected; Labour has embarked on a $£ 1.2$ billion programme of school repairs and building work needed after eighteen years in which the Conservatives administered education. Money will also be released to pay for the promise of class-size reduction by gradually phasing out of the Assisted Places Scheme.

During the 1997 election it was the promise of reducing the size of some primary school classes that was given prominence. In fact, Labour's promise on class-size is breathtakingly modest; implying as it does that some children in the 5-7 age-range might still find themselves in classes of more than 30 in 
the year 2000-1 and that children not in the 5-7 age-range might find themselves in classes of more than 30 even after 2002. Kirsty Milne (1998) points out that 'demography is in Labour's favour' because there is a small drop in the forecast number of primary-aged children between 1998-2000. Nevertheless, with a quarter of 5-7 year olds $(477,000)$ and a third of all primary school children being taught in classes of more than 30 in 1997-98, Labour's promise might be hard to achieve. Milne provides a detailed analysis which demonstrates the extent of the obstacles to this most modest of new Labour promises.

Writing before Labour's comprehensive spending review, which was announced by Chancellor Gordon Brown in the summer of 1998, Milne pointed to difficulties arising from Labour's electoral commitment to keep within old Tory spending limits during their first two years in government. She demonstrated that Labour's class-size policy could not be adequately funded by diverting public money released from the phasing-out of the Assisted Places Scheme (APS) as had been proposed. In the school year 1997-98 the APS had cost taxpayers around $£ 146$ million. But the money released by phasing-out was only to become available gradually because those elevenyear-olds starting on the APS in September 1997, for example, would continue to receive public finance until leaving the sixth-form. The first tranche of money diverted from the APS, ring-fenced for reducing class sizes and amounting to only about $£ 22$ million, was announced in early 1998; subsequently, local authority schools would have had to be 'content with a drip-drip effect' (Milne 1998). A study in 1997 by the Chartered Institute of Public Finance and Accountancy had also showed that the APS savings would not be sufficient to cover the cost of the extra teachers required by Labour's class-size policy. Even in the longer term, phasing-out the APS would only have freed-up a cumulative total of about $£ 100$ million by the year 2000, so it was necessary for the Chancellor of the Exchequer to make additional provision to fund Labour's class-size policy.

Labour hopes that, with the additional funding, their promise on class-size will be secured by 2001-2, but another difficulty lies in what Milne refers to as 'the parable of the 31st child'. Even with sufficient money to pay for extra teachers to keep classes down to thirty, Labour might only be able to keep its promise by denying 'parental choice'. The parents of children who would have been the 31st child (and others) will have to find places in schools which are not their first choice. Milne points out that this is 'the untold story behind Labour's class-size pledge: it flies in the face of the Tories' much-vaunted policy on parental choice'. But, of course, thousands of parents had no real choice but to place their children in classes of over thirty during the years in which the Conservatives trumpeted the benefits of the market and parental choice. With additional funding, and through a range of policies for improving schools, Labour hopes to do much better and to regain its reputation as a party which regards education as a priority.

Many of Labour's promises about improving schools have little to do with questions of choice and the market and might appear more like old Labour interventionism. New Labour wants, quite properly, to intervene on the 
question of standards of numeracy and literacy and to establish centres of excellence to spread good practice rather than rely on market competition. Labour wants to improve the quality of education for children with special needs and to encourage more integration into mainstream schooling. Labour wants to encourage schools to promote racial harmony and raise the educational achievement of ethnic minority pupils. Labour wants a homeschool contract in all schools, better partnership with parents and greater representation of parents on school governing bodies and LEAs. Labour wants 'Pandas' - performance and assessment reports that will include benchmark targets related to pupils' family backgrounds, and Labour wants national guidelines on homework 'so that schools, parents and pupils realise its importance in raising standards' and much more.

Labour's ambitious list of promises indicates that much needs to be done in education and the year 2002 is set as a target date. But some of Labour's policy changes were already coming into effect in 1998, and in addressing the issue of funding for students in higher education, for example, the new Labour government has already dared to go much further than the right wing Sir Keith Joseph and the left-of-centre John Smith. The Conservatives had floated the idea of radical reform during Sir Keith's period of office as Secretary of State for Education in the 1980s but shied away from it in fear of the electoral consequences; as did John Smith a decade later. In September 1997 the new Labour Government announced that from the academic year 1999/2000 'there will be no entitlement to maintenance grant' (DfEE 1997, p. 9) and laid plans for a system of 'up front' means-tested tuition fees and student maintenance loans to replace grants. Labour avoided the use of the phrase 'graduate tax', although the government is said to be 'looking at whether repayments might be collected through the Inland Revenue' (ibid. p. 8).

The notion of a 'graduate tax' had been on Labour's agenda in the early 1990s when Jeff Rooker was a Shadow Minister. His proposals (see Rooker 1993) were rejected by John Smith who insisted that the idea could not be allowed to appear in Ann Taylor's consultative green paper on education, Opening Doors to a Learning Society (Labour Party 1993). Under Smith's leadership the issue was effectively suppressed and Rooker lost his role as Shadow Spokesperson on Higher Education. However, the Labor Government in Australia had introduced a graduate tax in the late 1980s, and when Blair took over the leadership of his Party the idea came back on the agenda. Tony Blair and David Blunkett adopted a somewhat modified version of Sir Ron (now Lord) Dearing's proposals on student funding; but only after Labour had won the 1997 election.

Learning to Succeed, the Report of the National Commission on Education (1993) had argued that although the idea of a graduate tax had some 'immediate attractions' these had to be weighed against a range of complex technical problems involved in tax collection. Moreover, the Commission had concluded the 'the graduate tax is not a fair mechanism' ( $p .264$ ) and instead suggested that a 'pay as you go' repayment scheme 'is likely to be more attractive over the long run' (p. 265). Whether a repayment scheme is called a 'tax' or something else matters less than the detail; except, of course, to 
politicians wary of what they regard as a tax-sensitive electorate. Sir John Cassels, Director of the National Commission on Education, argued that the vast majority of taxpayers have not benefited from higher education and cannot be expected to go on funding its expansion. He suggested that students would have to start contributing to the cost of their courses but 'they must be able to defer payment until their earnings enable them to do so without hardship, through the tax system'. Cassels argued that Britain has 'one the most expensive higher education systems in the world in terms of public expenditure per full-time student, and at the same time many of those students are at or near the poverty line'. He also pointed to 'another paradox' which is that, 'well-off families in Britain actually receive more in education subsidies than poor families, because they use it much more and are so heavily subsidised to do so'. At the same time, he observed that 'many universities and colleges have clapped-out buildings' and much property that is shabby from undermaintenance and over use'.

Cassels' observation about the social inequality involved in access to higher education is important but other aspects of the argument are not entirely convincing. His suggestion that the vast majority of taxpayers have not benefited from higher education is true only in an immediate, individual sense. Most graduates do indeed benefit themselves to a certain extent but many of them are also a benefit to the economic and social institutions which go on to employ them. Whilst the new Labour government recognizes the economic and social benefits of higher education and is keen to expand opportunities, it wants individuals and their families to pay more of the cost. The plan for students' families to pay up-front means-tested contributions to tuition fees excludes the poorest families who will pay no fees at all, whilst well-off families will pay $£ 1000$ per year from Autumn 1998. Ron Dearing was reported to be unhappy with Labour's modifications; his committee had not wanted any up-front means-testing. But Labour and Dearing are agreed on the principle of replacing maintenance grants with student loans, and on the principle (but not the detail) of loan repayment on the basis of 'ability to pay'.

Well-off families who already sponsor their offsprings' university education will be minimally affected by the changes, and no doubt there are some parents who will be pleased to find that they are no longer formally responsible for student maintenance costs. The new arrangements do not fall easily into 'left' or 'right' categories and Labour appears to have calculated that whilst in politics it may not always be possible to please all of the people all of the time, the electoral consequences might not be quite as damaging as was once thought. Like the previous Conservative government, Labour claims to want to see more students taking up the opportunity of higher education and it is widely acknowledged that this will mean persuading more students from less well-off families, and more 'mature' students to consider applying to university. However, Labour's 'new way' in higher education, and the prospect of substantial long-standing debt at the end of a three-year degree course may not prove attractive to such students.

\section{CONCLUSION}


On returning to power in May 1997 Labour inherited an education system very different from the one in place when the Callaghan Government was defeated in 1979. An important change during the intervening years had been the centralisation of powers. At the same time, there was a transfer of aspects of the administrative and financial responsibility to educational institutions themselves, and a consequent decline of the power and responsibility of the local education authorities. Colleges of further education had been removed from local authority ownership and control; as had the polytechnics before gaining their new status as universities. Over a thousand schools had opted out of local education authority control to become direct grant maintained schools and almost all of the rest had very substantial responsibility for the administration of their own financial affairs and other aspects of their management; albeit within the context of a system of central government policing. There can be little doubt that the new forms of management of schools and the policing of teachers' work goes down well with the voters of 'middle England' whose electoral support new Labour must secure in order to win general elections. However, we cannot be sure precisely what particular issues were in the minds of those who voted Labour in May 1997 and it is doubtful that education is quite the electoral issue it is sometimes made out to be (see McKenzie 1993). Labour's tremendous electoral achievement is acknowledged by even the most hostile of its opponents but, nevertheless, Labour's huge parliamentary majority, $65.2 \%$ of the seats, was secured with only $44.4 \%$ of the vote. Certainly no overall majority for Labour's education policy, as such, can be read off from the results of the poll.

At the end of the 20th century the British education system stands at what the new right sees as a 'half-way house'. Over the last ten years much of the ground has been prepared for the kind of market system in education that the new right seeks to achieve. There is a quasi-market in which the users of education services have become what some observers regard as 'walking vouchers' so that funding is closely tied to participation rates. This does not appear to be unacceptable to new Labour but it is a small step to a fully fledged voucher system of the kind that the new right wants to see established and, given the opportunity, there is little that would prevent the new right from picking up where it left off. This is indeed the conclusion reached by Stuart Sexton in the final chapter of this collection. However, much will depend on future elections and on political circumstances. Labour itself might move much further towards the neo-liberal view on educational provision. And there is no knowing what might happen to the Conservative Party, or whether the new right will have influence through it in the future. Whilst it is not difficult to imagine Labour securing a second term of office it is impossible to gauge the political terrain during the early 2000 s.

There is, of course, much more to the politics of contemporary education policy than I have been able to refer to in this chapter. I have merely sketched out an argument about the changes of education policy over the last twenty years and provided some illustrations. I have left much of the detail on specific policy issues to the specialist contributors to the book. And in some respects a proper conclusion must be left till 2002 when we will be able assess the 
results of new Labour's promises and the electorate's verdict on the new Labour project as a whole. 